\title{
Way Forward for Nepalese Agriculture
}

\author{
Swodesh Rijal* \\ Faculty of Agriculture, Agriculture and Forestry University Rampur, Chitwan, Nepal \\ *Corresponding Author: Swodesh Rijal, Faculty of Agriculture, Agriculture and Forestry University, Rampur, Chitwan, Nepal
}

Received: July 09, 2019; Published: July 19, 2019

DOI: 10.31080/ASAG.2019.03.0582

Nepalese economy is totally dominated by Agriculture. According to Ministry of Finance (2075) the contribution of agriculture sector activities to Gross domestic products (GDP) is $27.6 \%$ in the current fiscal year 2017/2018. The agricultural sector where two third (more than 66 percent) of the population is engaged, is still of subsistence in nature. The Nepalese economy has shrunken to 5.0 is also indication of challenges in our economic condition. Moreover the farming condition is also meagerly weaker and no improvement in agriculture productivity. Low productivity, volatile pattern of growth, low level of investment and low technology input are major characteristics of Nepalese agriculture. In this circumstance, exertion of ensuing innovation, Entrepreneurship and Sustainability solutions to make farming practices more efficient remains one of the greatest imperatives. The ultimate future of farming predominately depends on adoption of cognitive solutions. So that way forward for Nepalese Agriculture is possible only through Innovation, Entrepreneurship and Sustainability.

\section{Innovation}

Innovation is a new idea, imagination, creative thought that convert into useful products. It shifts attention away from research and technology, towards whole process of innovation. Innovation is outcomes of "innovation systems" made up of organizations, private and public stakeholders which are interconnected in different ways and have technical, commercial and financial competencies and inputs necessary for innovation. The government plays a fundamental role to foster innovation. In our Nepalese we are on the way of agricultural improvement and some of possible innovations are:

- Product innovation: Changes or creation of goods. For example: we can diversified our maize product as maize mo:mo, Chowmein, Thuppa, corn syrup, corn cobs oil and glue.

- Process innovation: changes to the way goods are produced or services. For Example: process of production or delivered through online booking, pre-booking, fastest delivery etc.

- Marketing innovation: changes in way or changes in placement. For example: product information by poster, pamphlet, ICT.
Artificial intelligence, Drone pollination, Crop and soil monitoring, vertical farming, urban agriculture blockchain technology etc are implemented innovation in world.

\section{Entrepreneurship}

For the successful entrepreneurship there are two major things. They are entrepreneurial spirit and managerial skills in order to run a profitable farm business. Nowadays in this increasing complex global economy entrepreneurship plays a vital role for survival of small land holder farmer from under-developing country like Nepal. Agricultural entrepreneurship related mainly with commodity with their Benefit-cost (BC) ratio, profitability in long run, comparative advantages of production and resource utilization. In our Nepalese context entrepreneurship are totally depend on import substitution and Export potential. Here we must consider about problem of middleman in agriculture. Agriculture entrepreneurship is all about risk bearing ability. Moreover, majority of Nepalese youth are in foreign employment which causes entrepreneurship deficite condition. So, Nepalese government must adopt an appropriate policy that makes an agricultural entrepreneurship a attractive dignified profession. Also, private sector should be more active in commercial farming. If it happens then agriculture will definitely make Nepal more prosperous and self reliant.

\section{Sustainability}

Sustainability in agriculture is a production system without harming the environment. It has three major goals: social and economic equity, environmental health and economic profitability.

Subsistence level of farming, food insecurity, malnutrition, impact of climate change and agro-ecological conditions are challenges that shown the necessity of sustainability in Nepalese agriculture. We must promote organic level of production, practices of integrated pest/insect/nutrition management practices to achieve sustainability. Others possible sustainable practices are crop rotation, crop diversity, cover crop, vertical farming, water management etc.

In this way forward for Nepalese Agriculture is only through Innovation, Entrepreneurship and Sustainability. (figure 1) 


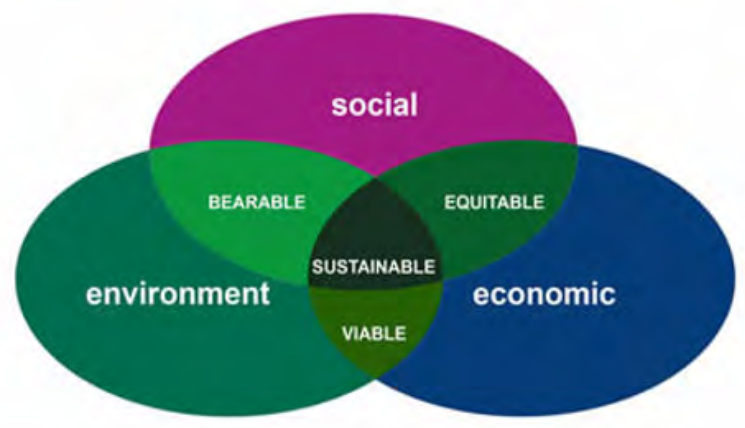

Figure

\section{Volume 3 Issue 8 August 2019}

(C) All rights are reserved by Swodesh Rijal. 